\title{
ASIAN FINANCIAL CRISIS: OVERVIEW OF ASIAN CRISIS AND RECOVERY PROGRESS
}

\author{
Noerlina ${ }^{1}$; Sylvia Cinthya Dewi ${ }^{2}$
}

\begin{abstract}
The rapid recovery in Asia economies in some ways of a surprise because many countries in Asia had tried a lot of ways to stabilize the economy from the crisis' pressure in 1997. As a result, most of these countries in Asia slowly recover by the step of restructuring in the financial sector, such as fiscal adjustment and the continuation of a floating exchange rate system.
\end{abstract}

Keywords: Asian, financial, crisis

\section{ABSTRAK}

Pemulihan ekonomi Asia yang pesat sangat mengejutkan karena banyak negara di Asia telah mencoba banyak cara untuk menstabilkan ekonomi dari tekanan krisis pada tahun 1997. Sebagai hasilnya, bayak negara di Asia perlahan-lahan pulih dalam sektor finansial, seperti penyusaian fiskal dan kelanjutan sistem nilai tukar mata uang.

Kata kunci: Asia, keuangan, krisis

${ }_{1,2}$ Staf Pengajar Fakultas Ekonomi, UBiNus, Jakarta 


\section{INTRODUCTION}

The floating of the Thai Baht in 1997 had caused a deep financial sector crisis in Asia. The crisis spread to other Asian countries and the interest of investors toward the region reduced significantly that led the economic activity like investment, consumption and export demand sharply declined.

As in Indonesia, the economic crisis in 1997/1998 was exceptionally difficult because this country experienced both financial/economic and political crises. Indonesia crisis has been deeper than other countries in Asia like Korea, Malaysia and Thailand. The recovery progress was very slow due to too many problems in the country region such as riot, corruption and heavy debt burden that led to negative foreign investment flows since 1997.

The banking sector reform in Indonesia is being carried out by the IBRA (Indonesian Bank Restructuring Agency), which is included as one of the Asset Management Vehicle (AMC) in Asia. There are also similar AMC vehicles in Asia like Korea Asset Management Corporation (KAMCO) in Korea, Danaharta in Malaysia and Financial Restructuring Authority (FRA) in Thailand. This will be discussed further in this paper. Due to the Asian financial turmoil of 1997, Asian has suffered severely. However, We believe that although they have all had to go through tough times, they have learned very valuable lessons in return.

The first and foremost lesson is the crisis prevention. All Asian countries need to prevent such crises in advance, each country must continually push forward with restructuring of its corporate and financial sectors, so that it can rid its economy of structural vulnerabilities. In the present international environment of advancing cross-border economic integration, each country must also strive to comply with international standards in areas of its statistical and accounting practices.

At the regional level, Asian countries need to have closer cooperative ties with each other. By setting up close communication networks, they can communicate and share information on each other's economic situation and on capital flows in the region. In this perspective, some issues related to key underlying assumptions and forecast results would be briefly addressed in the light of the latest information available.

\section{DISCUSSION}

\section{Overview of the Asian Crisis}

The Asian Crisis in 1997 was triggered off by the Thai bath devaluation. Since May 1997 the Thai's economy has been slowing down due to political instability, which in turn caused massive market speculations. In addition to that, the currency and stock market sharp fall has created a financial turmoil that affected Thai's economic fundamentals.

Due to the weakening macroeconomic conditions experienced by many South East Asian countries, these countries could neither increase their domestic business or their overseas exports. 
The financial crisis in Asia began with currency markets, however the instability of exchange rate occurred due to the problem within the banking sector. Many financial institutions and companies had borrowed in foreign currencies without adequate hedging, making them vulnerable to currency depreciation.

In many Asian countries, production has declined, whilst inflation and unemployment have shot up. The rapid decline in currencies and stock market levels marked the beginning of the Asian financial crisis. While Thai, Korean, Malaysian and Philippine's currencies had fallen 40 to $50 \%$, Indonesian Rupiah was experiencing a decline up to 500 to $600 \%$. This affects the local currencies that had to be used to service foreign loans. A tremendous increase in FOREX (Foreign Exchange) loss was then created.

Highly leveraged corporate sectors and large un-hedged short-term debt, those especially in Indonesia, Korea, Malaysia and Thailand, made these crisis countries vulnerable to changes in market sentiment, particularly to exchange and interest rate changes. Among other Asian countries, Malaysia and Philippines were less vulnerable. However, by the second round, when the crisis hit Taiwan, Singapore and Hong Kong's dollar, all countries were heavily affected by the crisis. Indonesia was the worst among the most affected countries. In order to help stabilize the economic of the above-mentioned countries (except Malaysia), the International Monetary Fund (IMF) immediately responded by providing funds of US\$ 35 billion. At the same time, IMF also designs plans to help those countries right to overturn their economies.

Despite IMF’s financial support to help Asian financial crisis, IMF was being criticized. This is due to their policy proposals that seem to favor international investors over domestic investors. Often times, IMF's recommendations give relaxation of the restrictions on foreign investment, which has led the sales of the business at a distressed price.

\section{Asian Recovery}

According to Asia Recovery Report 2000, Asia’s recovery has been encouraging and faster than expected but incomes and living standards have still a way to go to reach pre-crisis level. Korea has experienced the strongest recovery, while Indonesia is furthest behind and it is yet broad-based. Asset market has led the recovery, with exchange rates and equity valuations at the forefront, but property markets have yet to recover. Exports and public spending have driven recovery in the real economy, while private consumption and investment are beginning to track upward as well.

The domino effect of the Asian financial crisis brought about different policy responses across this part of the world. Therefore, as part of the financial sector reform progress in Asia, most of the countries in Asia established an asset management corporation (AMC). AMC is a liability agency, which facilitates the transfer of problem assets from financial institution to an expert management of problem loans with the process of maximizing net returns over a reasonable timeframe.

The government in Asia set up these AMC vehicle due to the banking sector failures that is high levels of non performing loans therefore it needs to recapitalize banks and repairing the balance sheet in those countries. These AMC vehicles have been established in several emerging market countries that is in Indonesia (Indonesian Banking Restructuring Agency), Malaysia 
(Danaharta), Thailand (Financial Sector Restructuring Authority), and Korea (Korea Asset Management Corporation).

Bank re-capitalization and restructuring is proceeding at an uneven pace. Korea and Malaysia were ranked as the fastest, Indonesia was the slowest while in Thailand it is considered to be moderate. Recovery is mainly cyclical not structural because recovery progress spread fast among other Asian countries. This way it could drive faster recovery in neighboring countries. Korea has the fastest recovery progress because the government really put a lot of effort to stabilize the country's economy. In Malaysia, because insolvency practices were based on the English model, restructuring therefore could be carried out quickly.

In Thailand, the insolvency process is similar to the civil law model; the process is very slow because of a great deal of court involvement that is required. Thailand is more focused on the liquidation than reorganization. Since 1999, the companies in Thailand were given a second chance to reorganize the company, rather than liquidation. This has made the law more attractive to the companies as there were an increasing number of companies that enter the insolvency process voluntarily. However, Thailand's law is very limiting, therefore it needs to adopt western approach in order to carry out the recovery more quickly.

Indonesia, on the other hand, is facing difficulties in solving the recovery progress. The country is under weak government institutions and robust political competition, which in turn cause a political instability. Its high level of corruption has made it even harder for the country to recover from the crisis.

\section{CONCLUSION}

Since July 1997, when the Thai bath collapsed, East Asia has experienced an unprecedented economic contraction and dramatic recovery. Although adjustment is not complete, there has been significant progress made in repairing balance sheets disrupted by recent financial crises.

Steps also have been taken to improve supervision and regulation. However, the biggest challenge facing East Asian policymakers is to decide how much of certain traditional institutional practices to keep, and how much to discard in favor of systems in place advanced market economies. Details recovery progress of the countries in Asia will be discussed further in next jurnal.

\section{REFERENCES}

Bank Indonesian, Indonesian Financial Statistics, various issues; Central Bureau of Statistics, Official Releases, various issues; Ministry of Finance, International Monetary Fund, International Financial Statistics, various issues; staff estimates.

Hesketh. W. June 2001. Notes of the Asian Financial Crisis. Jakarta: PT Deloitte Advisory. 
www.adb.org/Documents/Books/ADO/2002/ino.asp

http:www.cidse.org/pubs/tamingtigers.html\#1.\%20the\%20MFT

http://www.efic.gov.au/economics/020510.asp

http://www.economicjustice.org/resources/media/malaysiaIMF.html

www.globalpolicy.org/socecon/global/khorasre.htm

http://www.orrick.com/about/offices/tokyo/article4.htm

http://www.mof.go.th/ther_2/index_ther.html, 4/12/2000; FEER 7/9/98,67.

www.bppn.go.id

www.danaharta.gov.my

www.fra.or.th

www.kamco.or.kor 